\title{
Effects of composted swine manure on nutrient content in grains of Panicum miliaceum L.
}

\author{
Dionei Schmidt Muraro ${ }^{1 *}$, Fabiana Lima Abrantes ${ }^{2}$, Claudir José Basso ${ }^{3}$, Fabio Lima Abrantes ${ }^{4}$, Vanessa \\ Alba da Silva ${ }^{3}$, Adalin Cezar Moraes de Aguiar ${ }^{5}$, Ivan Ricardo Carvalho ${ }^{6}$, Henrique Pozebon ${ }^{3}$, Marcia \\ Gabriel $^{3}$, Marco Eustáquio de Sá ${ }^{4}$, Stela Maris Kulczynski ${ }^{3}$
}

${ }^{1}$ Department of Entomology and Acarology, University of São Paulo (ESALQ/USP) - Piracicaba, São Paulo, 13418900, Brazil

${ }^{2}$ Departmentof Agronomy College, University of Oeste Paulista (UNOESTE), Raposo Tavares Highway Km 572, Presidente Prudente, São Paulo 19067175, Brazil

${ }^{3}$ Department of Plant Protection, Federal University of Santa Maria (UFSM), Roraima Avenue 1000, Santa Maria, Rio Grande do Sul 97105900, Brazil

${ }^{4}$ Department of Plant Science, Food Technology and Economy Partner, São Paulo State University Julio de Mesquita Filho (UNESP), Monção Street 226, Ilha Solteira, São Paulo 15385-000, Brazil

${ }^{5}$ Department of Plant Science, Federal University of Viçosa (UFV), Avenida Peter Henry Rolfs, Viçosa, 36570-900, Brazil

${ }^{6}$ Department of Agrarian Sciences, Regional University of Northwestern Rio Grande do Sul, 98700-000, Brazil

\section{Abstract}

The aim of this work was to evaluate the effect of different doses of composted swine manure on protein and macronutrient contents of proso millet grains and in nutrient export by the crop. The experiment was carried out in the years 2013 and 2014 in a randomized block design, with four replications and five treatments, composed of four doses of composted swine manure $(0,4.0$, 8.0 and $12.0 \mathrm{Mg} \mathrm{ha}^{-1}$ ) and one dose of mineral fertilization (NPK 100-60-40 kg ha-1). Compost and mineral fertilizers were applied manually in each plot after the sowing of the crop, according to the established doses. After the harvesting, grain samples were taken to determine protein, $\mathrm{N}, \mathrm{P}, \mathrm{K}, \mathrm{Ca}, \mathrm{Mg}$ and $\mathrm{S}$ contents, as well as the amount of macronutrients exported by the crop. The data were submitted to analysis of variance. The means of the variables related to the compost doses were compared to the control plot (absence of fertilization) and to the mineral fertilization plot using the Tukey' test $(P \leq 0.05)$, and the effects of CSM doses were assessed by regression analysis, adopting as selection criteria the model and the magnitude of the regression coefficients at $5 \%$ of significance. The export of nutrients from the field by $P$. miliaceum grains at the dose of $4.0 \mathrm{Mg} \mathrm{ha}-1$ of compost was equal to the mineral fertilization recommended for the crop, justifying the use of swine manure as a substitute for mineral fertilization. The use of compost provides protein content in $P$. miliaceum grains similar to the use of mineral fertilizer.

Keywords: organic fertilizer, proso millet, pig slurry, composting, nutrient export, macronutrients.

Abbreviations: CSM_composted swine manure; NPK_nitrogen phosphorus potassium; ASL_above sea level.

Introduction

Proso millet (Panicum miliaceum L.) is a short cycle grass (Lu et al., 2009) native to East Asia (Bettinger et al., 2007) and well adapted to warm climates (Baltensperger et al., 1995; Berglund, 2007). The grass has emerged as an alternative to crop rotation under no-tillage system in the USA (Habiyaremye et al., 2017), where it is grown mainly in the spring. Though still sparsely cultivated in Brazil, $P$. miliaceum has attracted the attention of growers as an alternative for wheat cultivation during the winter, since its short cycle allows the subsequent sowing of soybean within its optimum sowing window (Basso et al., 2015). The crop presents low production costs and high straw formation rate, one of the basic premises in the no-tillage system (Basso et al., 2015; Muraro et al., 2016). Proso millet grains can be used to feed poultry (Guglieri et al., 2004) and produce beer (Zarnkow et al., 2010) and ethanol (Rose and Santra, 2013).

The use of swine waste as a nutritional source for agricultural crops has gradually increased in recent years (Meade et al., 2011) due to the resulting improvement in the chemical properties of the soil (Brito et al., 2005; Oliveira et al., 2014) and the lack of alternatives for the disposal of liquid swine waste in Brazil (Makara and Kowalsky, 2015; De Conti et al., 2016). Among the chemical elements typically present in swine waste, nitrogen (N) stands out in importance, since it is directly related to the grain yield of most crops and is usually required in large quantities (ElShaarawi et al., 2011). Composted swine manure (CSM) is obtained from the mixture of liquid swine manure (LSM) and sawdust substrate, resulting in an organic fertilizer with high dry matter content (53\%) and $\mathrm{N}$ in organic form. The 
mineralization of organic $\mathrm{N}$ occurs slowly and gradually, increasing the synchronism between demand and availability of $\mathrm{N}$ to the crops (Barrena et al., 2011) and avoiding environmental problems related to nitrogen loss (Prapaspongsa et al., 2010), such as eutrophication (Vitousek et al., 2009; MacDonald et al., 2011) and enhanced emission of $\mathrm{NH}_{3}, \mathrm{CO}_{2}$ and $\mathrm{N}_{2} \mathrm{O}$ to the atmosphere (Thu et al., 2012). Therefore, CSM effciency as a source of $\mathrm{N}$ to the plants is higher than that provided by liquid waste (Barrena et al., 2011) and even by mineral fertilizers (Sieling et al., 2014).

The use of CSM as fertilizer to $P$. miliaceum plants is known to increase dry mass production, number of grains per plant and grain yield (Silva et al., 2016), but there is scarcity of data concerning the effects CSM on grain composition and nutrient export in proso millet and other crops. Seidel et al. (2010) and Alves et al. (2017) evaluated the contents of N, P and $\mathrm{K}$ in maize leaves and grains, respectively, and observed no difference between organic and mineral fertilizers. Silva et al. (2015), on the other hand, verified that the use of swine manure resulted in significant increases in protein, $\mathrm{N}$, $\mathrm{P}, \mathrm{Ca}$ and $\mathrm{Mg}$ levels in Brachiaria decumbens plants. Abrantes et al. (2011) found that the moment of nitrogen application did not affect significantly the export of macronutrients by proso millet grains, though variations were observed in the $\mathrm{N}, \mathrm{P}, \mathrm{K}, \mathrm{Ca}, \mathrm{Mg}$ and $\mathrm{S}$ export levels according to the dose of $\mathrm{N}$ used. The controversy observed between the existing data, therefore, justifies further studies on the subject.

The aim of this work was to evaluate the effect of different doses of composted swine manure (CSM) on protein and macronutrient contents of proso millet grains and in nutrient export by the crop.

\section{Results and Discussion}

\section{Nutrient content in the grains}

Protein and nitrogen contents in $P$. miliaceum grains varied according to the treatments used (Table 1), but no significant difference was observed for protein (Figure 1 ) and nitrogen (Figures $2 \mathrm{~A}$ and $2 \mathrm{~B}$ ) content in the two cropping seasons, in relation to the different CSM doses supplied to the crop. Similar results were obtained by Abrantes et al. (2011) and Muraro et al. (2016), who also did not observe significant differences in the protein content of proso millet grains when using different doses of inorganic-release nitrogen. According to Kelling and Fixen (1992), when the demand of $\mathrm{N}$ for plant growth and grain production is satisfied, further additions of $\mathrm{N}$ are directed by the plant to increase the protein content of the grains. In this sense, it is possible that the doses of $\mathrm{N}$ provided to the crop (both in organic and inorganic form) did not exceed the minimum levels required for plant growth and development, since protein content in the grains from the control plots (absence of fertilization) was statistically similar to the treatments with mineral fertilization and with the highest dose of CSM (Table 1, Figure 1).

Phosphorus content in the proso millet grains varied among the treatments. In the first year, the treatment without fertilization (control) presented data statistically similar to the treatments with 4 and $8 \mathrm{tha}^{-1}$ of CSM, and these differed only from the treatments with $12 \mathrm{t} \mathrm{ha}^{-1}$ of CSM and with mineral fertilization (NPK). Similarly, the control treatment did not differ from any other treatment in the second year, indicating that the accumulation of phosphorus in the grains was not influenced by the phosphorus supplied to the crop (Table 1).

Potassium content in the proso millet grains was also not influenced by fertilization in the first year, since the highest potassium content was observed in the treatment without fertilization (control). In the second year, however, the highest potassium content was observed when the crop received mineral fertilization (NPK), even though the CSM fertilizer contained potassium in a much larger concentration than that provided by mineral fertilization. No statistical difference was observed in the second year among the treatments with 0,4 and $12 \mathrm{t} \mathrm{ha}^{-1}$ of CSM, all of which presented an intermediate level of potassium; the lower level was observed when $8 \mathrm{t} \mathrm{ha}^{-1}$ of CSM were supplied to the crop (Table 1).

Calcium content in the proso millet grains was not significantly influenced by the fertilizing treatments. In the 2013 cropping season, magnesium levels were higher in the treatment without fertilization and with $4 \mathrm{t} \mathrm{ha}^{-1}$ of CSM, while in 2014 the treatment with $8 \mathrm{t} \mathrm{ha}^{-1}$ of CSM differed only from the treatments without fertilization (control) and with mineral fertilization (NPK). Sulfur content in the grains varied considerably among the treatments in 2013, with the highest levels observed in the treatments without fertilization (control), with mineral fertilization (NPK) and with $4 \mathrm{t} \mathrm{ha}^{-1}$ of CSM; in 2014, however, there was no significant difference among the treatments (Table 1).

The comparison of nutrient levels from the first year indicates that phosphorus, potassium, magnesium and sulphur contents in the proso millet grains were linearly reduced by increased doses of CSM, while nitrogen and calcium levels were not significantly affected (Figure 2A). In 2014 , on the other hand, there was no influence of the CSM doses in the nitrogen, phosphorus, potassium, calcium, magnesium and sulphur levels of the proso millet grains (Figure 2B).

\section{Nutrient export by the crop}

Nitrogen export by $P$. miliaceum grains in the two cropping seasons was not significantly influenced by $\mathrm{N}$ supply, either through CSM or mineral fertilization (Table 2). However, evaluation of export values according to the CSM doses revealed an increasing line until the calculated doses of 8.9 and $11.3 \mathrm{t} \mathrm{ha}^{-1}$ of CSM for the years 2013 and 2014, respectively, with a reduction in export values above these doses (Figures $3 \mathrm{~A}$ and $3 \mathrm{~B}$ ).

Phosphorus export by proso millet grains varied significantly among the treatments. The highest export values were obtained in the treatments with 4 and $8 \mathrm{tha}^{-1}$ of CSM, in the first year, and with $12 \mathrm{t} \mathrm{ha}^{-1}$ of CSM and mineral fertilization, in the second year (Table 2). The effect of the CSM doses in 2013 displayed a quadratic behaviour (with the highest export provided by the calculated dose of $5.8 \mathrm{t} \mathrm{ha}^{-1}$ ), while in 2014 there was a linear increase on exported phosphorus levels according to the CSM doses (Figures $3 \mathrm{~A}$ and $3 \mathrm{~B}$ ).

The amount of potassium exported in the first year was higher in the treatment that received $8 \mathrm{tha}^{-1}$ of CSM, differing from all other treatments except $4 \mathrm{t} \mathrm{ha}^{-1}$ of CSM. In the second year, however, the application of $8 \mathrm{t} \mathrm{ha}^{-1}$ of CSM resulted in the lowest export level, differing significantly only from the treatment with mineral fertilization (Table 2). 
Table 1. Protein, nitrogen $(\mathrm{N})$, phosphorus $(\mathrm{P})$, potassium $(\mathrm{K})$, calcium $(\mathrm{Ca})$, magnesium $(\mathrm{Mg})$ and sulphur $(\mathrm{S})$ contents in $P$. miliaceum grains in relation to composted swine manure (CSM) and mineral fertilization (NPK) doses. Cropping seasons 2013 and 2014.

\begin{tabular}{|c|c|c|c|c|c|c|c|}
\hline \multirow{2}{*}{ Treatment (fertilizer dose) } & \multirow{2}{*}{ Protein (\%) } & $\mathrm{N}$ & $P$ & $\mathrm{~K}$ & $\mathrm{Ca}$ & $\mathrm{Mg}$ & $\mathrm{S}$ \\
\hline & & \multicolumn{6}{|c|}{$\mathrm{g} \mathrm{kg}^{-1}$} \\
\hline & & 2013 & & & & & \\
\hline 0 & $10.9 a b^{*}$ & $17.5 \mathrm{ab}$ & $3.3 \mathrm{a}$ & $4.8 \mathrm{a}$ & $1.6 \mathrm{a}$ & $0.8 \mathrm{a}$ & $2.5 \mathrm{a}$ \\
\hline 4 t ha-1 $^{-1}$ (CSM) & $9.9 \mathrm{~b}$ & $15.9 \mathrm{~b}$ & $3.4 \mathrm{a}$ & $4.4 \mathrm{a}$ & $1.5 \mathrm{a}$ & $0.9 \mathrm{a}$ & $2.0 \mathrm{ab}$ \\
\hline 8 t ha $^{-1}(\mathrm{CSM})$ & $10.2 \mathrm{ab}$ & $16.4 \mathrm{ab}$ & $3.2 \mathrm{a}$ & $4.7 \mathrm{a}$ & $1.9 \mathrm{a}$ & $0.5 b$ & $1.6 \mathrm{bc}$ \\
\hline 12 t ha-1 $^{-1}(\mathrm{CSM})$ & $10.5 a b$ & $16.7 \mathrm{ab}$ & $1.8 \mathrm{~b}$ & $3.4 \mathrm{~b}$ & $2.0 \mathrm{a}$ & $0.3 \mathrm{~b}$ & $1.2 \mathrm{c}$ \\
\hline $100-60-40 \mathrm{~kg} \mathrm{ha}^{-1}$ (NPK) & $11.6 \mathrm{a}$ & $18.5 \mathrm{a}$ & $2.0 \mathrm{~b}$ & $4.0 \mathrm{ab}$ & $1.7 \mathrm{a}$ & $0.3 \mathrm{~b}$ & $2.6 \mathrm{a}$ \\
\hline \multirow[t]{2}{*}{ CV (\%) } & 5.9 & 5.8 & 17.7 & 10.1 & 19.2 & 29.9 & 14.8 \\
\hline & & 2014 & & & & & \\
\hline 0 & $12.1 \mathrm{ab}$ & $19.5 \mathrm{ab}$ & $3.0 \mathrm{abc}$ & $4.9 \mathrm{~b}$ & $1.6 \mathrm{a}$ & $0.9 \mathrm{a}$ & $2.5 \mathrm{a}$ \\
\hline 4 t ha-1 $^{-1}$ CSM) & $11.2 \mathrm{~b}$ & $18.0 \mathrm{~b}$ & $2.1 \mathrm{bc}$ & $3.9 b$ & $1.8 \mathrm{a}$ & $0.7 \mathrm{ab}$ & $1.8 \mathrm{a}$ \\
\hline 8 t ha-1 $^{-1}$ (CSM) & $12.7 \mathrm{a}$ & $20.3 a$ & $1.6 \mathrm{c}$ & $2.1 \mathrm{c}$ & $2.0 \mathrm{a}$ & $0.3 \mathrm{~b}$ & $2.0 \mathrm{a}$ \\
\hline 12 t ha- $^{-1}(\mathrm{CSM})$ & $11.3 \mathrm{~b}$ & $18.2 \mathrm{~b}$ & $3.6 \mathrm{a}$ & $4.4 b$ & $2.0 \mathrm{a}$ & $0.7 \mathrm{ab}$ & $1.7 \mathrm{a}$ \\
\hline $100-60-40 \mathrm{~kg} \mathrm{ha}^{-1}$ (NPK) & $13.1 \mathrm{a}$ & $21.0 \mathrm{a}$ & $3.3 \mathrm{ab}$ & $6.4 \mathrm{a}$ & $1.8 \mathrm{a}$ & $1.2 \mathrm{a}$ & $2.1 \mathrm{a}$ \\
\hline $\mathrm{CV}(\%)$ & 4.8 & 4.8 & 23.2 & 14.5 & 12.9 & 31.8 & 19.5 \\
\hline
\end{tabular}

${ }^{*}$ Means followed by the same lowercase letter in the column do not differ among themselves by the Tukey test $(\mathrm{P} \leq 0.05)$.

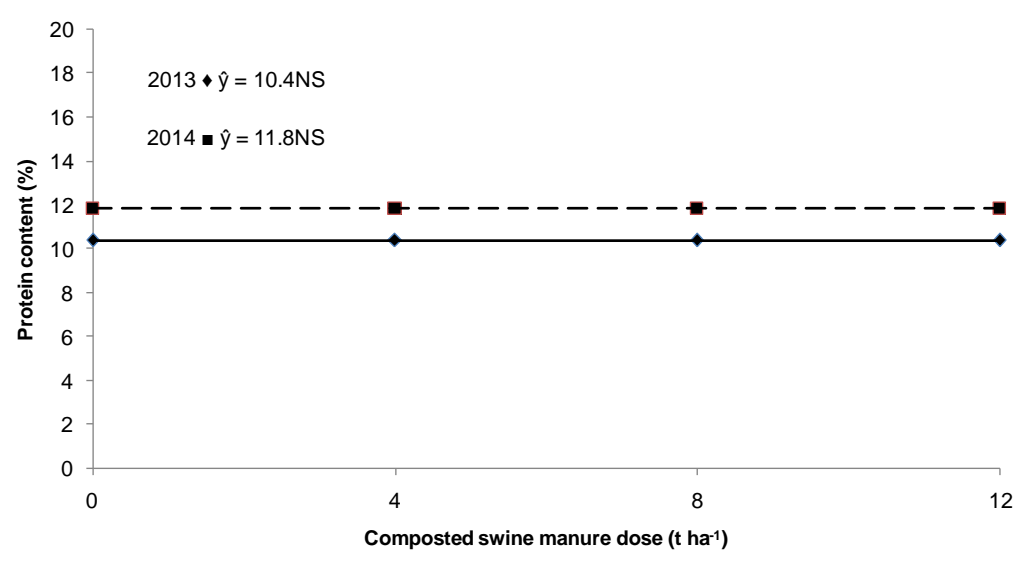

Fig 1. Protein content in P. miliaceum grains (\%) in relation to composted swine manure (CSM) doses $\left(\mathrm{t} \mathrm{ha}^{-1}\right)$. Cropping seasons 2013 and 2014.

Table 2. Nitrogen $(\mathrm{N})$, phosphorus $(\mathrm{P})$, potassium $(\mathrm{K})$, calcium $(\mathrm{Ca})$, magnesium $(\mathrm{Mg})$ and sulphur $(\mathrm{S})$ amounts exported by $P$. miliaceum grains in relation to composted swine manure (CSM) and mineral fertilization (NPK) doses. Cropping seasons 2013 and 2014.

\begin{tabular}{|c|c|c|c|c|c|c|}
\hline \multirow{2}{*}{ Treatment (fertilizer dose) } & $\mathrm{N}$ & $\mathrm{P}$ & $\mathrm{K}$ & $\mathrm{Ca}$ & $\mathrm{Mg}$ & $\mathrm{S}$ \\
\hline & \multicolumn{6}{|c|}{$\mathrm{kg} \mathrm{ha}^{-1}$} \\
\hline & 2013 & & & & & \\
\hline 0 & $38.5 b^{*}$ & $7.2 \mathrm{bc}$ & $10.7 \mathrm{~b}$ & $3.5 \mathrm{~b}$ & $2.0 \mathrm{ab}$ & $5.5 \mathrm{a}$ \\
\hline $4 \mathrm{t} \mathrm{ha}^{-1}(\mathrm{CSM})$ & $44.7 \mathrm{ab}$ & $9.7 a b$ & $12.2 \mathrm{ab}$ & $4.7 \mathrm{ab}$ & $2.7 \mathrm{a}$ & $5.5 \mathrm{a}$ \\
\hline $8 \mathrm{t} \mathrm{ha}^{-1}(\mathrm{CSM})$ & $62.5 \mathrm{a}$ & $12.2 \mathrm{a}$ & $18.0 \mathrm{a}$ & $7.2 \mathrm{a}$ & $1.7 \mathrm{abc}$ & $5.7 \mathrm{a}$ \\
\hline $12 \mathrm{t} \mathrm{ha}^{-1}(\mathrm{CSM})$ & $52.7 \mathrm{ab}$ & $5.5 \mathrm{c}$ & $11.0 \mathrm{~b}$ & $6.5 a b$ & $1.0 \mathrm{bc}$ & $3.7 \mathrm{a}$ \\
\hline $100-60-40 \mathrm{~kg} \mathrm{ha}^{-1}$ (NPK) & $44.2 \mathrm{ab}$ & $4.7 c$ & $9.2 \mathrm{~b}$ & $4.0 \mathrm{ab}$ & $0.7 c$ & $6.2 \mathrm{a}$ \\
\hline \multirow[t]{2}{*}{ CV (\%) } & 19.6 & 23.1 & 21.5 & 30.4 & 32.3 & 24.7 \\
\hline & 2014 & & & & & \\
\hline 0 & $20.8 \mathrm{~b}$ & $3.2 \mathrm{~b}$ & $5.2 \mathrm{ab}$ & $1.7 \mathrm{~b}$ & $1.0 \mathrm{a}$ & $2.7 \mathrm{a}$ \\
\hline $4 \mathrm{t} \mathrm{ha}^{-1}(\mathrm{CSM})$ & $27.7 a b$ & $3.5 b$ & $6.0 a b$ & $3.0 \mathrm{ab}$ & $1.2 \mathrm{a}$ & $3.2 \mathrm{a}$ \\
\hline $8 \mathrm{t} \mathrm{ha}^{-1}(\mathrm{CSM})$ & $38.3 \mathrm{a}$ & $3.2 b$ & $4.5 \mathrm{~b}$ & $4.0 \mathrm{a}$ & $0.75 a$ & $3.7 \mathrm{a}$ \\
\hline $12 \mathrm{t} \mathrm{ha}^{-1}(\mathrm{CSM})$ & $36.5 \mathrm{a}$ & $7.0 \mathrm{a}$ & $8.7 a b$ & $4.0 \mathrm{a}$ & $1.5 \mathrm{a}$ & $3.5 \mathrm{a}$ \\
\hline $100-60-40 \mathrm{~kg} \mathrm{ha}^{-1}$ (NPK) & $30.7 \mathrm{ab}$ & $5.2 \mathrm{ab}$ & $9.7 \mathrm{a}$ & $3.0 \mathrm{ab}$ & $1.7 \mathrm{a}$ & $3.5 \mathrm{a}$ \\
\hline CV (\%) & 19.2 & 34.4 & 32.3 & 24.2 & 55.6 & 32.9 \\
\hline
\end{tabular}




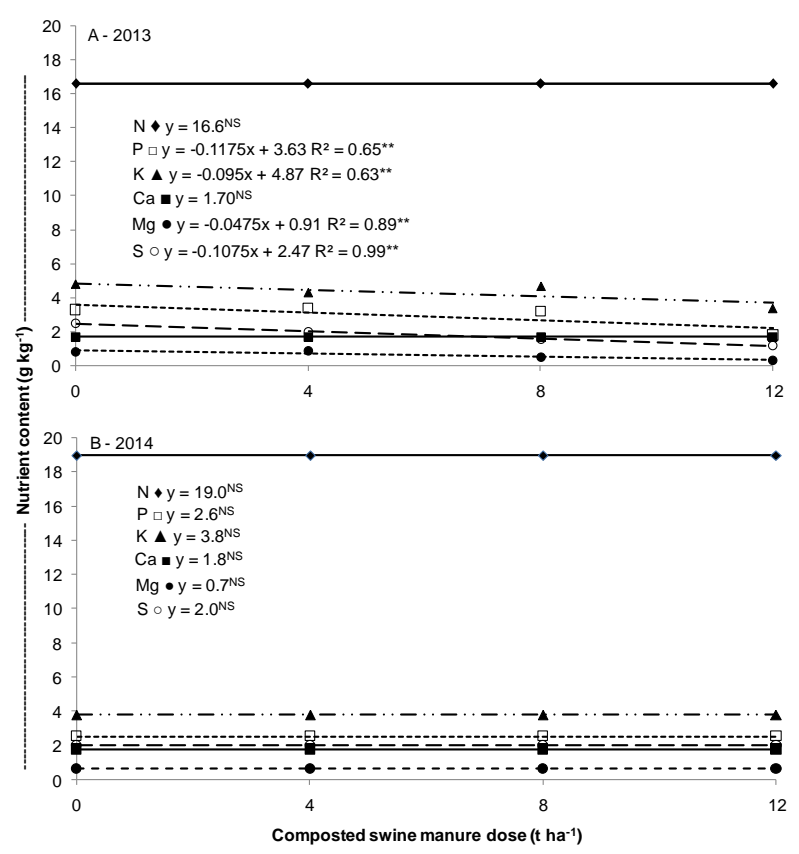

Fig 2. Nitrogen $(\mathrm{N})$, phosphorus $(\mathrm{P})$, potassium $(\mathrm{K})$, calcium $(\mathrm{Ca})$, magnesium $(\mathrm{Mg})$ and sulphur $(\mathrm{S})$ contents in $P$. miliaceum grains $(\mathrm{g}$ $\mathrm{kg}^{-1}$ ) in relation to composted swine manure (CSM) doses ( $\mathrm{t} \mathrm{ha}{ }^{-1}$ ). Cropping seasons 2013 and 2014.

Table 3. Chemical characteristics of the composted swine manure (CSM) in each of the doses used.

\begin{tabular}{lllllll}
\hline & $\mathrm{N}$ & $\mathrm{P}$ & $\mathrm{K}$ & $\mathrm{Ca}$ & $\mathrm{Mg}$ \\
\cline { 2 - 6 } & $\mathrm{g} \mathrm{kg}^{-1}$ & & & & \\
\cline { 2 - 6 } & 29.4 & & 4 & 24.7 & 17.8 & 5.6 \\
\hline $\mathrm{Mg} \mathrm{ha}^{-1}$ & $\mathrm{~kg} \mathrm{ha}^{-1}$ added & & & & & \\
\hline 4 & 117.6 & 16 & 98.8 & 71.2 & 22.4 & \\
8 & 235.2 & 32 & 197.6 & 142.4 & 44.8 & \\
12 & 352.8 & 48 & 296.4 & 213.6 & 67.2 & \\
\hline
\end{tabular}

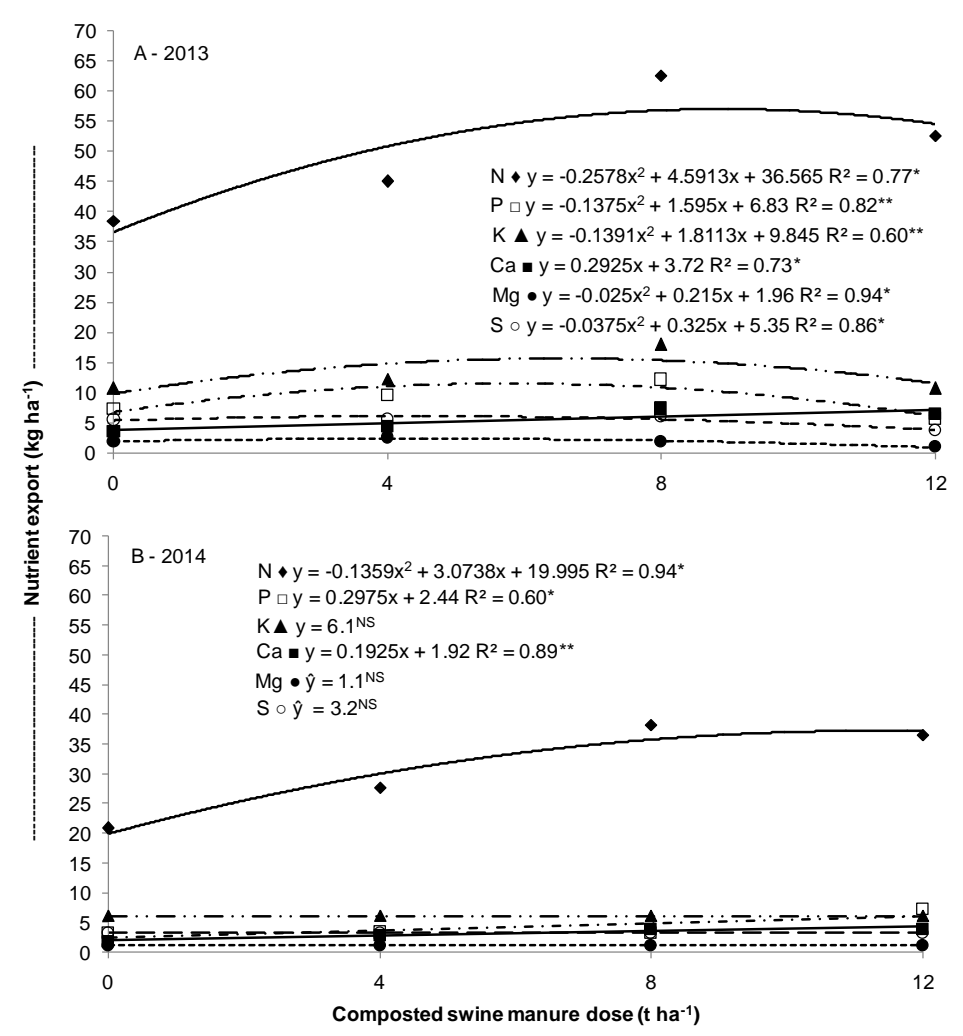

3. Nitrogen $(\mathrm{N})$, phosphorus $(\mathrm{P})$, potassium $(\mathrm{K})$, calcium $(\mathrm{Ca})$, magnesium $(\mathrm{Mg})$ and sulphur $(\mathrm{S})$ amounts exported by $P$. miliaceum grains ( $\mathrm{kg} \mathrm{ha}^{-1}$ ) in relation to composted swine manure (CSM) doses ( $\left.\mathrm{t} \mathrm{ha}^{-1}\right)$. Cropping seasons 2013 and 2014. 
Regarding the effect of CSM doses, the amount of potassium exported in 2013 increased until the calculated dose of $6.5 \mathrm{t}$ ha $^{-1}$, while in 2014 there was an initial decrease followed by an increase (Figures $3 \mathrm{~A}$ and $3 \mathrm{~B}$ ).

Export levels for calcium in 2013 differed only between the application of $8 \mathrm{t} \mathrm{ha}^{-1}$ of CSM and the control treatment, which presented the lowest value. In 2014, the only significant difference was between the control and the applications of 8 and $12 \mathrm{t} \mathrm{ha}^{-1}$ of CSM (Table 2). The export of this nutrient by proso millet grains increased with higher doses of CSM in the two cropping seasons (Figures $3 \mathrm{~A}$ and $3 B)$.

The amount of magnesium exported in 2013 varied significantly among the treatments with $4 \mathrm{t} \mathrm{ha}^{-1}$ of CSM, $12 \mathrm{t}$ ha ${ }^{-1}$ of CSM and mineral fertilization. In 2014, on the other hand, no difference was observed among the treatments (Table 2). Regarding the effect of CSM doses, there was a quadratic increase in magnesium export in 2013 (with a maximum value provided by the calculated dose of $4.3 \mathrm{t}$ ha$\left.{ }^{1}\right)$, while in 2014 no significant difference was observed (Figures $3 \mathrm{~A}$ and $3 \mathrm{~B}$ ). The same quadratic behaviour and maximum point were found for the sulphur content in proso millet grains, whose exported amounts in the two years were not statistically influenced by the treatments (Table 2).

\section{Implications on fertilization programs}

Phosphorus, potassium and sulphur contents in the proso millet grains and export values for $\mathrm{N}, \mathrm{P}, \mathrm{K}, \mathrm{Ca}, \mathrm{Mg}$ and $\mathrm{S}$ were overall higher than those observed by Abrantes et al. (2011) in the same cultivar, while protein, nitrogen, calcium and magnesium contents in the grains were similar. The protein content found was also similar to the values observed by Kalinova and Moudry (2006) in different cultivars of $P$. miliaceum.

Fertilization with CSM provided export values for $\mathrm{N}, \mathrm{P}, \mathrm{K}, \mathrm{Ca}$, $\mathrm{Mg}$ and $\mathrm{S}$ equal or higher than those obtained with mineral fertilization (NPK), indicating that composted swine manure can be as efficient as mineral fertilization in the supply and export of nutrients in the proso millet crop. Alves et al. (2017) also did not find significant differences between the use of swine manure and mineral fertilizer for the accumulation of $\mathrm{N}, \mathrm{P}$ and $\mathrm{K}$ in maize grains.

Regardless of the treatment used, nutrient export values followed the order $\mathrm{N}>\mathrm{K}>\mathrm{P}>\mathrm{S}>\mathrm{Ca}>\mathrm{Mg}$, differing from Abrantes et al. ( $\mathrm{N}>\mathrm{P}>\mathrm{Ca}>\mathrm{S}>\mathrm{K}>\mathrm{Mg}$ ) in their evaluation of doses and moments of $\mathrm{N}$ supply to $P$. miliaceum. This result indicates that export order is influenced by the amount of nutrients supplied to the crop as well as its availability in the soil, since the experimental area used by the aforementioned authors presented lower availability of nutrients than the soil of this experiment. Teruel and Smiderle (1999) also state that differences in plant species, crop varieties and amounts of nutrients in the soil or supplied through fertilization can cause divergence between the results.

Regarding the effect of different CSM doses, nutrient export responses varied considerably among macronutrients, and the responses observed in the first cropping season were not maintained in the second; for some nutrients the doses were not significant, and for others increased doses resulted in lower concentration in the grains. Animal waste is known to present an exceptionally variable chemical composition, with certain nutrients in disproportionate amounts to the plants' needs; mineral fertilizers, on the other hand, are formulated according to soil and crop conditions, and these characteristics certainly influenced the large variation in export responses among the macronutrients in the two agricultural years.

The yield of agricultural crops is directly related to the balance of elements available in the soil, since both insufficient and excessive amounts are detrimental to the growth and development of the plants. This relation was discussed by Voisin (1965), who stated that insufficiency (law of the minimum) or excess (law of the maximum) of a nutrient element in the soil reduces the efficiency of the others and decreases the yield of crops in general. The use of composted swine manure, therefore, requires particular attention on the physical and chemical properties of the soil and the extraction capacity of the plants, in order to avoid imbalance of nutrients and its detrimental effects on grain yield of proso millet and other crops.

\section{Materials and Methods}

\section{Experimental site}

The experiment was carried out during the years 2013 and 2014, in the experimental area of the Federal University of Santa Maria, campus of Frederico Westphalen - RS $\left(27^{\circ} 23^{\prime} 59^{\prime \prime} \mathrm{S}, 53^{\circ} 25^{\prime} 16^{\prime \prime} \mathrm{W}, 566\right.$ meters a.s.l.). The climate of the site is defined as subtropical humid ( $\mathrm{Cfa}$ ) according to Köppen's classification (Alvares et al., 2013). The soil of the site is classified as Typical Distrophic Red Latosoil, with medium clayey texture (EMBRAPA, 2013). A chemical analysis of the soil was carried out, in which the following chemical characteristics were observed in the $0-20 \mathrm{~cm}$ depth layer: $\mathrm{pH}$ (in water) $=4.6$; SMP index $=5.1$; clay content $=$ $650 \mathrm{~g} \mathrm{~kg}^{-1}$; organic matter content $=2.7 \mathrm{~g} \mathrm{~kg}^{-1}$; phosphorus (Mehlich extractor) $=7.2 \mathrm{mg} \mathrm{dm}^{-3}$; potassium $=137 \mathrm{mg} \mathrm{dm}^{-3}$; calcium $=2.1 \mathrm{cmol}_{c} \mathrm{dm}^{-3} ;$ magnesium $=1.2 \mathrm{cmol}_{C} \mathrm{dm}^{-3}$; hydrogen + aluminum $=8.0 \mathrm{cmol}_{c} \mathrm{dm}^{-3} ;$ aluminium $=2.1$ $\mathrm{cmol}_{c} \mathrm{dm}^{-3}$; cation exchange capacity (CTC) $=11.6 \mathrm{cmol}_{c} \mathrm{dm}^{-3}$; saturation by bases $=31.3 \%$; saturation by aluminum $=36$, $5 \%$. Six months prior to the experiment setting, limestone was applied to raise the $\mathrm{pH}$ of the soil to 6.0 , following the recommendation from the Comission for Soil Chemistry and Fertility (CQFS-RS/SC, 2004).

\section{Plant material}

Cultivation of $P$. miliaceum was carried out under no-tillage system. In both years, soybean crop (Glycine max) preceded the cultivation of proso millet, with the area left fallow after soybean harvest for a period of three months. Prior to sowing the area was sprayed with glyphosate $\left(3 \mathrm{~L} \mathrm{ha}^{-1}\right.$ of commercial product). Sowing was carried out on September $14^{\text {th }}(2013)$ and August $22^{\text {th }}(2014)$, using the cultivar AL Tibagi, spaced $0.45 \mathrm{~m}$ between rows and with a density of 120 seeds $\mathrm{m}^{-1}$. Plant emergence occurred at 10 days after sowing for both years, with the cycle duration being 87 and 93 days for the years 2013 and 2014, respectively.

\section{Composted swine manure}

Composted swine manure (CSM) is obtained from the mixture of liquid swine manure (LSM) and sawdust substrate with a high $\mathrm{C} / \mathrm{N}$ ratio, resulting in a dry, solid organic fertilizer. The mixture is constantly revolved to promote water evaporation from animals' urine and feces (Fukumoto 
et al., 2011). The manure/substrate ratio must be equal or higher than $8: 1$, to increase the concentration of manure nutrients and reduce the volume of waste generated. The compost used in both experimental years was obtained in the city of Concordia - SC, Brazil, where the liquid waste resulted from pig farming activity is treated and converted into CSM, according to the process described above. A sample of the compost was sent to laboratory for chemical analysis and macronutrient quantification, in which the following chemical characteristics were observed: $\mathrm{N}=29.4 \mathrm{~g}$ $\mathrm{kg}^{-1} ; \mathrm{P}=4 \mathrm{~g} \mathrm{~kg}^{-1} ; \mathrm{K}=24.7 \mathrm{~g} \mathrm{~kg}^{-1} ; \mathrm{Ca}=17.8 \mathrm{~g} \mathrm{~kg}^{-1} ; \mathrm{Mg}=5.6 \mathrm{~g}$ $\mathrm{kg}^{-1}$ (Table 3). The amount of nutrients added per hectare, according to each dose of compost, are also shown in Table 3.

\section{Experimental design and treatments evaluated}

The experimental design was a randomized block design, with five treatments and four replicates, and an area of 14.4 $\mathrm{m}^{2}$ per plot $(4.0 \times 3.6 \mathrm{~m})$. The treatments were comprised of four composted swine manure (CSM) doses $(0,4.0,8.0$ and $12.0 \mathrm{Mg} \mathrm{ha}^{-1}$ ) and one dose of mineral fertilization NPK (100$60-40 \mathrm{~kg} \mathrm{ha}^{-1}$ ), using as minerals sources urea (100 kg ha-1 of $\mathrm{N})$, single superphosphate (60 kg ha-1 of $\left.\mathrm{P}_{2} \mathrm{O}_{5}\right)$ and potassium chloride $\left(40 \mathrm{~kg} \mathrm{ha}^{-1}\right.$ of $\left.\mathrm{K}_{2} \mathrm{O}\right)$. Compost and mineral fertilizers were applied manually in each plot after the sowing of the crop, according to the established doses.

\section{Traits measured}

After harvesting, grain samples (100 g) were taken to a forced air oven ( 60 으, 72 hours), grounded and submitted to chemical analysis. Crude protein content was determined by multiplying the total $\mathrm{N}$ value by the 6.25 factor (AOAC, 1995), and the levels of $\mathrm{N}, \mathrm{P}, \mathrm{K}, \mathrm{Ca}, \mathrm{Mg}$ and $\mathrm{S}$ were quantified following the methodology described by Malavolta et al. (1997). The amounts of macronutrients exported by the crop (i.e. nutrient removal per hectare) were calculated by multiplying the nutrient contents in the grains $\left(\mathrm{g} \mathrm{kg}^{-1}\right)$ by the grain yield (dry basis) of the crop ( $\mathrm{kg} \mathrm{ha}^{-1}$ ), with subsequent conversion of the values to $\mathrm{kg} \mathrm{ha}^{-1}$.

\section{Statistical analysis}

The data were submitted to analysis of variance. The means of the variables related to the CSM doses were compared to the control plot (absence of fertilization) and to the mineral fertilization plot using the Tukey' test $(P \leq 0.05)$, and the effects of CSM doses were assessed by regression analysis, adopting as selection criteria the model and the magnitude of the regression coefficients at $5 \%$ of significance. The software Genes ${ }^{\circ}$ (Cruz, 2013) was used for the statistical analyses.

\section{Conclusion}

Composted swine manure at a dose of $4.0 \mathrm{Mg}^{-1}$ provides an export of nutrients by $P$. miliaceum grains equal to the obtained with the recommended mineral fertilization for the crop, and can replace mineral fertilization in soil conditions similar to those used in this study. The use of composted swine manure as fertilizer provides protein content in $P$. miliaceum grains similar to the obtained with the use of mineral fertilization.

\section{References}

Abrantes FL, Kulczynski SM, Soratto RP, Barbosa MMM (2011) Nitrogênio em cobertura, teor de proteína e exportação de nutrientes pelos grãos de painço. Biosci J. 27: 888-895.

Alvares CA, Stape JL, Sentelhas PC, De Moraes G, Leonardo J, Sparovek G (2013) Köppen's climate classification map for Brazil. Meteorol Z. 22: 711-728.

Alves CTF, Cassol PC, Sacomori W, Gatiboni LC, Ernani PR, Aita A, Panisson J, Ferreira AKT (2017) Influência da adubação com dejeto suíno e adubo mineral adicionada de inibidor de nitrificação sobre a produtividade e a nutrição do milho. Rev Ciênc Agrovet. 16: 2-10.

AOAC - Association of Official Analytical Chemists (1995) Official methods of analysis. AOAC, Washington, USA.

Baltensperger DD, Lyon DJ, Anderson R, Holman T, Stymieste C, Shanahan J, Nelson L, DeBoer K, Hein G, Krall J (1995) Producing and marketing proso millet in the high plains. University of Nebraska, Lincoln, USA.

Barrena R, Turet J, Busquets A, Farrés M, Font X, Sánchez A (2011) Respirometric screening of several types of manure and mixtures intended for composting. Bioresour Technol. 102: 1367-1377.

Basso CJ, Somavilla L, Santi AL, Lamego FP, Caron BO, Muraro DS, Pansera E, Silva RF (2015) Rates and application times of nitrogen in proso millet crop. Biosci J. 31:1030-1036.

Berglund DR (2007) Proso millet in North Dakota. North Dakota State University, Fargo, USA.

Bettinger RL, Barton L, Richerson PJ, Boyd R, Wang H, Choi W (2007) The transition to agriculture in northwestern China. Dev Quat Sci. 9: 83-101.

Brito OR, Vendrame PRS, Brito RM (2005) Alterações das propriedades químicas de um latossolo vermelho distroférrico submetido a tratamentos com resíduos orgânicos. Semin Cienc Agrar. 26: 33-40.

CQFS-RS/SC - Comissão de química e fertilidade de solo (2004) Manual de adubação e calagem para os estados do Rio Grande do Sul e Santa Catarina. Sociedade Brasileira de Ciência do Solo, Porto Alegre, Brazil.

Cruz CD (2013) Genes - a software package for analysis in experimental statistics and quantitative genetics. Acta Sci Agron. 35(3): 271-276.

De Conti L, Ceretta C, Ferreira P, Lourenzi C, Girotto E, Lorensini F, Tiecher T, Marcheza C, Anchieta M, Brunetto G (2016) Soil solution concentrations and chemical species of copper and zinc in a soil with a history of pig slurry application and plant cultivation. Agric Ecosyst Environ. 216(15): 374-386.

El-Shaarawi AFI, Sabh AZ, Abou-Taleb SM, Ghoniem AE (2011) Effect of inorganic nitrogen and Bradyrhizobium japonicum inoculation on growth and yield of soybean. Aust J Basi \& Appl Sci. 5: 436-447.

EMBRAPA - Empresa Brasileira de Pesquisa Agropecuária (2013) Sistema brasileiro de classificação de solos, 3rd edn. Embrapa, Brasília, Brazil.

Fukumoto Y, Suzuki K, Kuroda K, Waki M, Yasuda T (2011) Effects of struvite formation and nitratation promotion on nitrogenous emissions such as NH3, N2O and NO during swine manure composting. Bioresour Technol. 102(2): 1468- 1474.

Guglieri A, Zuloaga FO, Longhi-Wagner HM (2004) Sinopse das espécies de Panicum L. subg. Panicum (Poaceae, Paniceae) ocorrentes no Brasil. Acta Bot Brasilica. 18: 359367. 
Habiyaremye C, Matanguihan JB, Guedes JD, Ganjyal GM, Whiteman MR, Kidwell KK, Murphy KM (2017) Proso millet (Panicum miliaceum L.) and its potential for cultivation in the pacific northwest, U.S.: a review. Front Plant Sci. 7: 1961.

Kalinova J, Moudry J (2006) Content and quality of protein in proso millet (Panicum miliaceum L.) varieties. Plant Foods Hum Nutr. 61: 45-49.

Kelling KA, Fixen PE (1992) Soil and nutrient requeriments for oat production. In: Marshall HG, Sorrelis ME (eds) Oat science and technology. American Society of Agronomy, Madison, USA.

Lu H, Zhang J, Liu KB, Wu N, Li Y, Zhou K, Ye M, Zhang T, Zhang H, Yang X, Shen L, Xu D, Li Q (2009) Earliest domestication of common millet (Panicum miliaceum) in east Asia extended to 10,000 years ago. Proc Natl Acad Sci U S A. 106(25): 7367-7372.

MacDonald GK, Bennett EM, Potter PA, Ramankutty N (2011) Agronomic phosphorus imbalances across the world's croplands. Proc Natl Acad Sci U S A. 108(25): 30863091.

Makara A, Kowalski Z (2015) Pig manure treatment and purifcation by fltration. Environ Eng Manag J. 161(3): 317324.

Malavolta E, Vitti GC, Oliveira AS (1997) Avaliação do estado nutricional de plantas: princípios e aplicações. Potafos, Piracicaba, Brazil.

Meade G, Pierce K, Doherty JVO, Mueller C, Lanigan G, Cabe TMc (2011) Ammonia and nitrous oxide emissions following land application of high and low nitrogen pig manures to winter wheat at three growth stages. Agric Ecosyst Environ. 140: 208-217.

Muraro DS, Basso CJ, Damian JM, Santi AL (2016) Management of nitrogen fertilization for the millet culture (Panicum miliaceum L.). Aust J Basi \& Appl Sci. 10: 20-26.

Oliveira DA de, Pinheiro A, Veiga M da (2014) Effects of pig slurry application on soil physical and chemical properties and glyphosate mobility. Rev Bras Ciênc Solo. 38(5): 14211431.

Prapaspongsa T, Christensen P, Schmidt JH, Thrane M (2010) LCA of comprehensive pig manure management incorporating integrated technology systems. J Clean Prod. 18: $1413-1422$.
Rose DJ, Santra DK (2013) Proso millet (Panicum miliaceum L.) fermentation for fuel ethanol production. Ind Crop Prod. 43(1): 602-605.

Seidel EP, Gonçalves Junior AC, Vanin JP, Strey L, Schwantes D, Nacke H (2010) Aplicação de dejetos de suínos na cultura do milho cultivado em sistema de plantio direto. Acta Sci Technol. 32: 113-117.

Sieling K, Ni K, Kage H (2014) Application of pig slurry: first year and residual effects on yield and $\mathrm{N}$ balance. Eur $\mathrm{J}$ Agron. 59(1): 13-21.

Silva AA, Lana AMQ, Lana RMQ, Costa AM (2015) Fertilização com dejetos suínos: influência nas características bromatológicas da Brachiaria decumbense alterações no solo. Eng Agríc. 35: 254-265.

Silva NA, Basso CJ, Muraro DS, Ortigara C, Pansera E (2016) Pig slurry composting as a nitrogen source in proso mille tcrop. Pesq Agropecu Trop. 46: 80-88.

Teruel DA, Smiderle OJ (1999) Trigo. In: Castro PRC, Klunge A (eds) Ecofisiologia de cultivos anuais: trigo, milho, soja, arroz e mandioca. Nobel, São Paulo, Brazil.

Thu CTT, Cuong PH, Hang LH, Chao NV, Anh LX, Trach NX, Sommer SG (2012) Manure management practices on biogas and non-biogas pig farms in developing countries using livestock farms in Vietnam as an example. J Clean Prod. 27: 64-71.

Vitousek PM, Naylor R, Crews T, David MB, Drinkwater LE, Holland E, Johnes PJ, Katzenberger J, Martinelli LA, Matson PA, Nziguheba G, Ojima D, Palm CA, Robertson GP, Sanchez PA, Townsend AR, Zhang FS (2009) Agriculture nutrient imbalances in agricultural development. Science. 324(4): 15199-1520.

Voisin A (1965) Fertilizer application: soil, plant, animal. Crosby Lockwood, London, UK.

Zarnkow M, Back W, Gastl M, Arendt EK (2010) Impact of proso millet (Panicum miliaceum L.) varieties on malting quality. J Am Chem Soc. 68(1): 152-159. 